\title{
Estimating the Potential Production of the Brown Mussel Perna perna (Linnaeus, 1758) Reared in Three Tropical Bays by Different Methods of Condition Indices
}

\author{
Petrus Galvao, ${ }^{1,2}$ Renan Longo, ${ }^{2}$ João Paulo Machado Torres, ${ }^{2}$ and Olaf Malm ${ }^{2}$ \\ ${ }^{1}$ Programa de Pós Graduação do Instituto Carlos Chagas Filho, Universidade Federal do Rio de Janeiro, \\ 21941-900 Rio de Janeiro, RJ, Brazil \\ ${ }^{2}$ Laboratório de Radioisótopos Eduardo Penna-Franca, Universidade Federal do Rio de Janeiro, 21941-900 Rio de Janeiro, RJ, Brazil \\ Correspondence should be addressed to Petrus Galvao; mgpetrus@biof.ufrj.br
}

Received 16 June 2014; Revised 25 November 2014; Accepted 15 December 2014

Academic Editor: Tracy K. Collier

Copyright (C) 2015 Petrus Galvao et al. This is an open access article distributed under the Creative Commons Attribution License, which permits unrestricted use, distribution, and reproduction in any medium, provided the original work is properly cited.

Perna perna (Linnaeus, 1758) is the main marine bivalve mussel yielded commercially in Brazil. In spite of this, scientific data is very scarce regarding its productivity in tropical shallow waters. The Condition Index (CI) is used worldwide in mariculture to assess animal health, harvest time, and yield. In this study, the authors used CI results from nine different methods to assess the season effect on the mussel CI and also to evaluate the potential yield of three southern Brazilian bays. The results from nine CI methods were used for the comparison of the seasonality and yield of mussels reared in three marine bays. Sampling was carried out monthly within two 4-month periods, from December 2008 to August 2009. The results show a trend for seasonal effects on the CI results. The winter months showed the highest and the lowest values. Between bays, higher CI values were detected in animals reared at Sepetiba Bay, followed by Guanabara Bay and Ilha Grande Bay. We suggest that the CI (that considers the ratio between bivalve soft tissue wet weight and total length) should be used by fishermen, since this formula was able to detect differences between sites and is more easily applied.

\section{Introduction}

Marine mussel farming activity has increased almost $20 \%$ around the world from 1999 to 2008 [1]. The marine mussel Perna perna (Linnaeus, 1758) (Mollusca: Bivalvia) belongs to the Mytilidae family and is one of the most cultivated bivalves in Brazil, representing 19\% of the total produced by the entire Brazilian mariculture.

The Condition Index (CI) has been used as a tool to evaluate the physiological state of bivalve health. The CI provides useful information for shellfish farmers, since it indicates the commercial quality of the animals [2] and the best growing area or cultivation process [3]. There is an understanding that these animals show different physiological activity (growth, reproduction, and excretion, among others) in different environmental conditions and that the CI can summarize these variations [4]. Previous studies have been conducted in order to address the parameters responsible for CI fluctuations. It has been demonstrated that the CI is influenced by the gametogenesis stage of the animal, when there is a decrease of body mass in the transition period from the last spawning and the inactive sexual stage, as the interfollicular space is not yet filled by connective tissue [5]. Low food availability (low organic seston and phytoplankton) and primary spawning during the summer have been related to the lowest CI values observed in P. perna in a tropical bay [6]. High temperatures can also inhibit spawning [7]. Studies have showed that mussels collected from contaminated sites present lower CI values when compared to animals from less impacted areas [8]. A positive relationship between polychlorinated biphenyls (PCBs) and the CI has been also observed, which could be understood as the intake of these contaminants with food consumption, with no negative impact of these chemicals on 


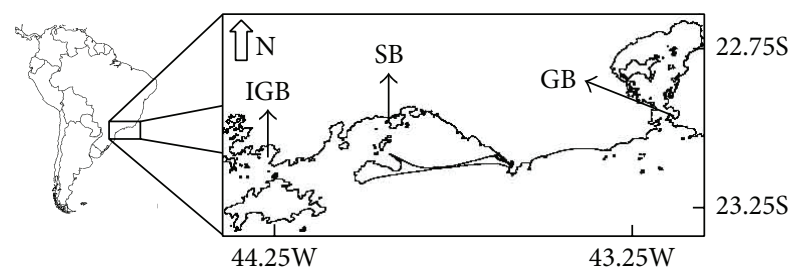

FIGURE 1: Study area. The three sampling sites are referred to as the bay name of their location. Guanabara Bay (GB); Sepetiba Bay (SB); Ilha Grande Bay (IGB). The arrows start at the approximate location of the sampling sites. The image showing the site coordinates was acquired from http://www.ngdc.noaa.gov/mgg/shorelines/shorelines/lines.html.

physiological parameters [9]. Additionally, seasons can play an important role in the CI variation but do not influence the cytochemical response in mussel [10].

Different proposed methods to estimate the CI are available in the literature, but there is no agreement about which one is the most accurate. Total shell and soft tissue weight, internal volume, and total length are the parameters most used in CI equations. Previous studies have been conducted in order to discuss the more reliable CI equation found in the literature, but the suggested method (net growth efficiency) [4] is difficult to calculate and requires a well-equipped laboratory to perform the precise determinations. This represents the main constraint for this method to be widely adopted in marine bivalve farming, especially in undeveloped countries where low technologies are often applied in marine farms.

When we consider mariculture in tropical areas we can observe that very few CI data are available in indexed journals, and this piece of information is even scarcer when we search for papers specifically regarding the mussel $P$. perna.

It is important to highlight the wide range worldwide distribution of the brown mussel $P$. perna, which comprises India, Sri Lanka, the Atlantic Coast of South America, North America, and many Caribbean islands [11]. Additionally, the $\mathrm{CI}$ is not restricted to marine farming activity. It is also widely used as a biological parameter in studies of environmental contamination, to assess the relation between the contaminants concentrations and the mussel health. We consider that this paper provides quite valuable data to whom might adopt the P. perna as a biological model in environmental studies

In order to assess the most sensitive CI method equation between nine frequently used methods in the literature, this study compares the productivity of $P$. perna yield in three tropical coastal bays, as well the seasonality effects on CI values.

\section{Material and Methods}

Mussels were reared by longline systems and sampled in sea farming areas at three bays: Guanabara Bay (GB), Sepetiba Bay (SB), and Ilha Grande Bay (IGB) (Figure 1). Sampling was performed in summer (December, January, February, and March) and in winter (June, July, August, and September) from 2008 to 2009.
The three bays show different contamination patterns. GB $\left(412 \mathrm{~km}^{2}\right)$ is surrounded by 12 cities, including the capital of Rio de Janeiro State (Rio de Janeiro city). The total number of inhabitants surrounding the GB is approximately 11 million, and only about $25 \%$ of the domestic sewage shows secondary treatment [31]. Including the drainage basin, there are about 12000 industries, surrounded by two oil refineries, two navy bases, and a shipyard [32]. Since 1992 a mussel farming activity has been in development at the internal southeast portion of $\mathrm{GB}$, around five $\mathrm{km}$ from open sea waters; it is supported by an association of marine farmers and is responsible for an annual production of $130 \mathrm{t}$ and $65 \mathrm{t}$ in 2005 and 2006, respectively [33]. We had access to one of these farmers, who provided all the necessary logistics to conduct the field work at Jurujuba Beach.

The second sampling site, located in $\mathrm{SB}$, is an experimental marine farm at Itacuruça Island $\left(22^{\circ} 57^{\prime} 04^{\prime \prime} \mathrm{S}\right.$; $043^{\circ} 54^{\prime} 28^{\prime \prime} \mathrm{O}$ ), situated at the northern portion of this bay, at approximately $10 \mathrm{~km}$ from the main pollution source of SB (São Francisco channel and Guandu River), which is responsible for the main input of organic contaminants [34] at this site. The main industrial activities in the area consist of metallurgic enterprises and the local port, where the huge Sepetiba Harbor is located.

The final sampling site has been used as a reference station in ecotoxicological studies, due to its lower environmental contamination levels [35]. Nevertheless, a shipyard, an oil terminal, and a nuclear power plant exist nearby and are potential sources of contaminants into the IGB ecosystem. The laboratory of a marine mussel farming named POMAR that belongs to the "Instituto de Ecodesenvolvimento da Baía de Ilha Grande" (IEDBIG) is located near the shipyard, and the mussels naturally attached to the "longline" structures from this laboratory at Biscaia Inlet $\left(23^{\circ} 01^{\prime} 38^{\prime \prime} \mathrm{S}\right.$; $\left.044^{\circ} 14^{\prime} 14^{\prime \prime} \mathrm{O}\right)$ were used.

Nine CI equations were chosen from the literature to provide different approaches regarding CI estimation. The criteria in selecting these methods were based, mainly, on their assessment viability by the shellfish farmer involved in mariculture activity and on being a useful tool for bivalve production. Since one uses different CI calculation methods, it is expected that different aspects of environmental and biological variations may be reflected by each equation. When different CI equations are used to compare cases and all of the applied methods indicate a difference between the cases, we can consider that the cases are consistently distinct. The methods are described as follows:

CI I: [soft tissue dry weight $(\mathrm{g})] \times[$ fresh shell weight $(\mathrm{g}) \times 100]^{-1}[12]$,

CI II: [soft tissue wet weight $(\mathrm{g})] \times[$ fresh shell weight $(\mathrm{g}) \times 100]^{-1}[12]$,

CI III: [soft tissue wet weight $(\mathrm{g}) \times 100] \times[$ total animal fresh weight $(\mathrm{g})]^{-1}[36]$,

CI IV: [soft tissue dry weight $(\mathrm{g})] \times[$ internal cavity volume $(\mathrm{mL}) \times 100]^{-1}[37]$,

CI V: [soft tissue wet weight $(\mathrm{g})] \times[$ shell length $(\mathrm{mm})$ $\times 100]^{-1}[10]$, 
CI VI: [soft tissue dry weight $(\mathrm{g})] \times 100 \times[$ shell length $(\mathrm{cm})]^{-1}[22]$,

CI VII: [soft tissue dry weight $(\mathrm{g}) \times 100] \times[$ total animal dry weight $(\mathrm{g})]^{-1}[6]$,

CI VIII: [soft tissue dry weight $(\mathrm{g})] \times 100 \times$ [whole fresh weight $(\mathrm{g})$ - shell fresh weight $(\mathrm{g})]^{-1}[38]$,

CI IX: [soft tissue dry weight $(\mathrm{g})] \times[$ cubic shell length $\left.\left(\mathrm{cm}^{3}\right)\right]^{-1}[28]$.

CI IV, described by Rebelo and collaborators [37], requires more time and manual work in order to determine the internal cavity volume, but it is a feasible method to be applied by bivalve producers.

Thirty specimens of $P$. perna of commercial size $(6-8 \mathrm{~cm}$ total length) were sampled monthly from each sampling site during the summer and winter months. Mussels were sampled from a longline farming system, in depths from $1.5 \mathrm{~m}$ to $2 \mathrm{~m}$. As the field work was performed during two days per month, it was not possible to obtain biometric measurements on fresh animals, so the samples were taken to the laboratory and frozen at $-18^{\circ} \mathrm{C}$. Before measurements the specimens were thawed at room temperature. The epibionts were removed, the external bissus section was cut, and total body wet weight was obtained. The soft tissue was desiccated by cutting the adductor muscle and removing the internal bissus portion. After this, the shell and wet soft tissues were weighed $( \pm 0.01 \mathrm{~g}$ precision). Soft tissues were frozen again $\left(-70^{\circ} \mathrm{C}\right)$. Soft tissue dry weight was measured after lyophilization. Total shell length was determined using a digital caliper $( \pm 0.02 \mathrm{~mm}$ precision).

To compare the CI I data reported here to values observed in the literature, it is important to note that we did not place the fresh soft tissue on a paper towel as originally described [36]. We believe that, for mariculture purposes, this could become an obstacle, so the soft tissue was compressed in the analyst's hands to extract as much water as possible while still maintaining tissue integrity and then weighed, obtaining the final soft tissue wet weight. The authors were not able to evaluate if this modification has an effect on data comparability for this method. Nevertheless, it does not impair the conclusions of the present paper because they are based on the comparisons between the results of each of the studied bays.

It was not possible to perform method CI IV on the samples collected in August at SB, as the shells were very fragile and did not allow shaping the internal cavity volume model to assess the internal volume.

All analyzed mussels were grown by the "longline" method, which means that the animals were submerged the whole time, allowing nonstop contact with their food source. This is important to note before comparing our data with the literature, as one might find systems where the mussels are pulled out of water for a few hours up to a day and dropped into the water again to prevent excess biofouling on the organism's shells, which most likely reduces the feeding rate of the animals.

The total length (TL) means from all the analyzed animals was approximately $7.5 \mathrm{~cm}$ and the soft tissues wet weight

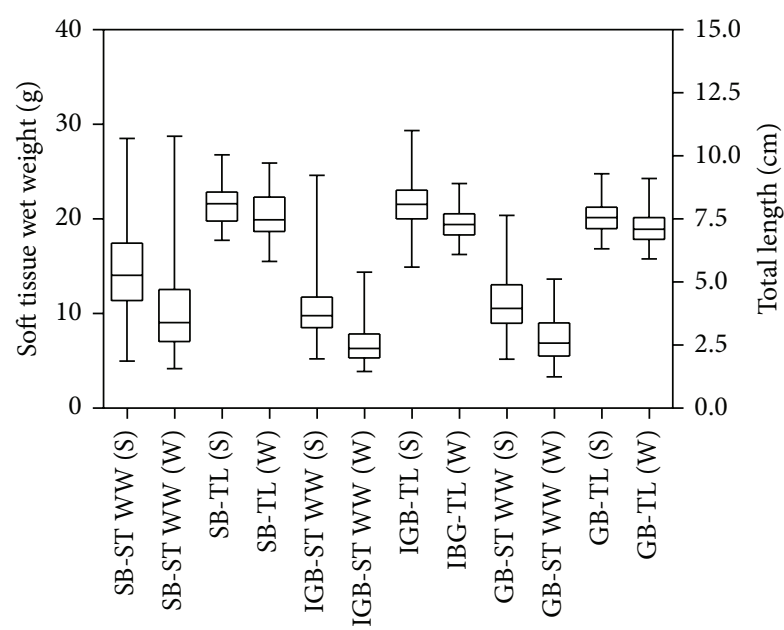

Figure 2: Basics biometric parameters of the studied organisms from the three bays: Sepetiba Bay (SB), Ilha Grande Bay (IGB), and Guanabara Bay (GB). Soft tissue wet weight (ST WW) and total length (TL) are shown in box and whiskers plots. Data is divided by summer (S) and winter (W). The horizontal line inside the box represents the median value, box represents the data range of 25$75 \%$, and the whiskers are the minimum and maximum values.

(ST WW) means was $10.0 \mathrm{~g}$ (Figure 2). Although some data found in the literature indicates that no relationship is observed between size and CI [39], we observed one study that indicates that larger soft tissue weights are related to higher CI values [40].

The statistical data analyses were performed on Graphpad Prism 5.0 (GraphPad Software Inc.) platform. Normality was assessed by the Shapiro-Wilk test and the difference on variances with the Kruskall-Wallis test and Dunns' post hoc test was applied to identify the differences between the sampling sites. The significance level for all tests was considered as $5 \%$. With the intent of evaluating the seasonality effect on the observed CI values, we ranked the CI values (from highest to lowest) obtained by each method from each bay. In addition, we verified the significant differences (Dunns' test) between the first and the second highest $\mathrm{CI}$ values in relation to the $\mathrm{CI}$ values of the following months.

\section{Results}

When analyzing the differences between the sampling months at each bay (Tables 1, 2, and 3), December showed the highest values of $\mathrm{CI}$ in all methods in most of the cases. In cases where December is not the highest one, it comes in second place, but with no significant difference to the first placed month. The exception to this was observed at IGB for CI method VIII, where December is the fourth placed month, but with no significant difference in comparison to the other top three placed months. When we observe the second month with higher CI values, summer months are always present, alternating between January, February, and March. CI II and CI VII at GB are the exceptions. In this case August appears in second place but shows no significant difference regarding the third placed month which is a summer month (February). Moving to the bottom of the rank, winter months appear in 


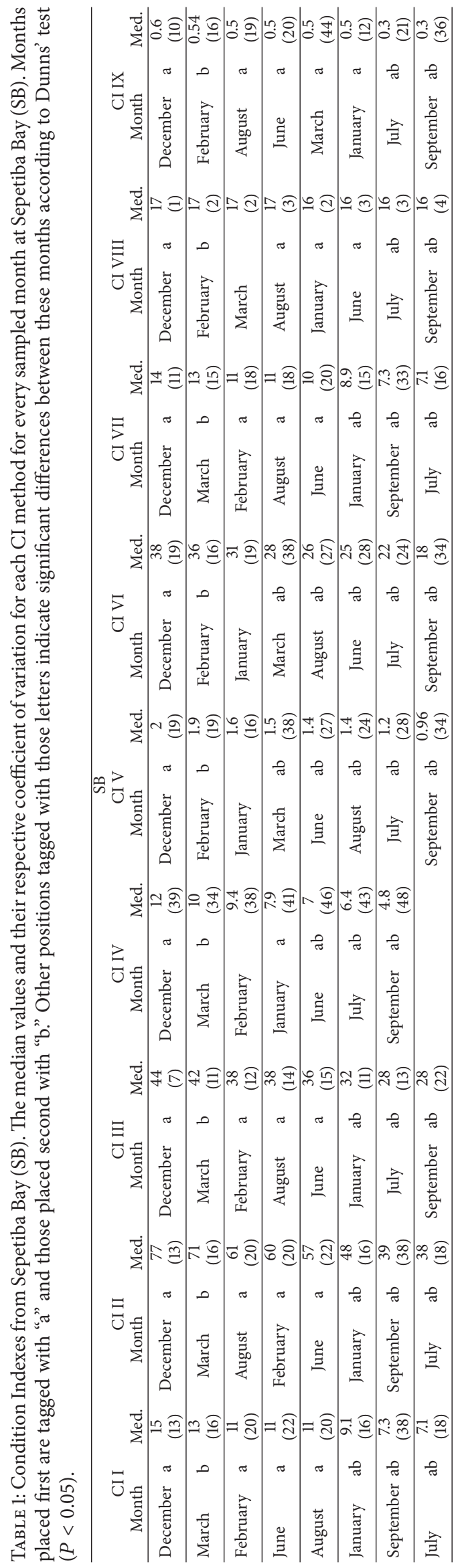




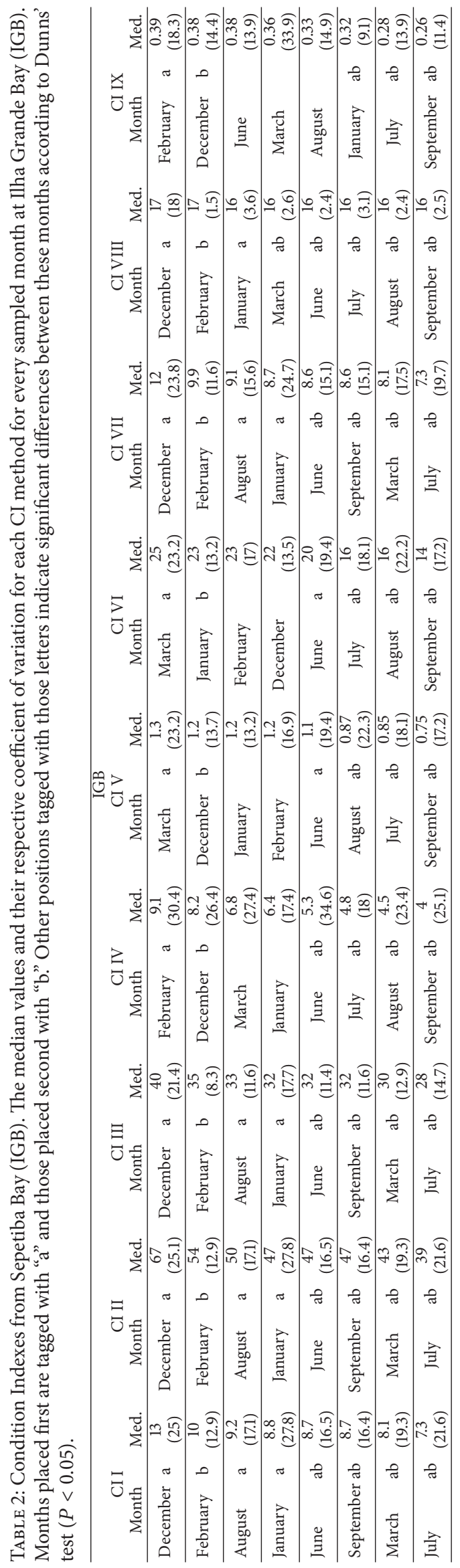




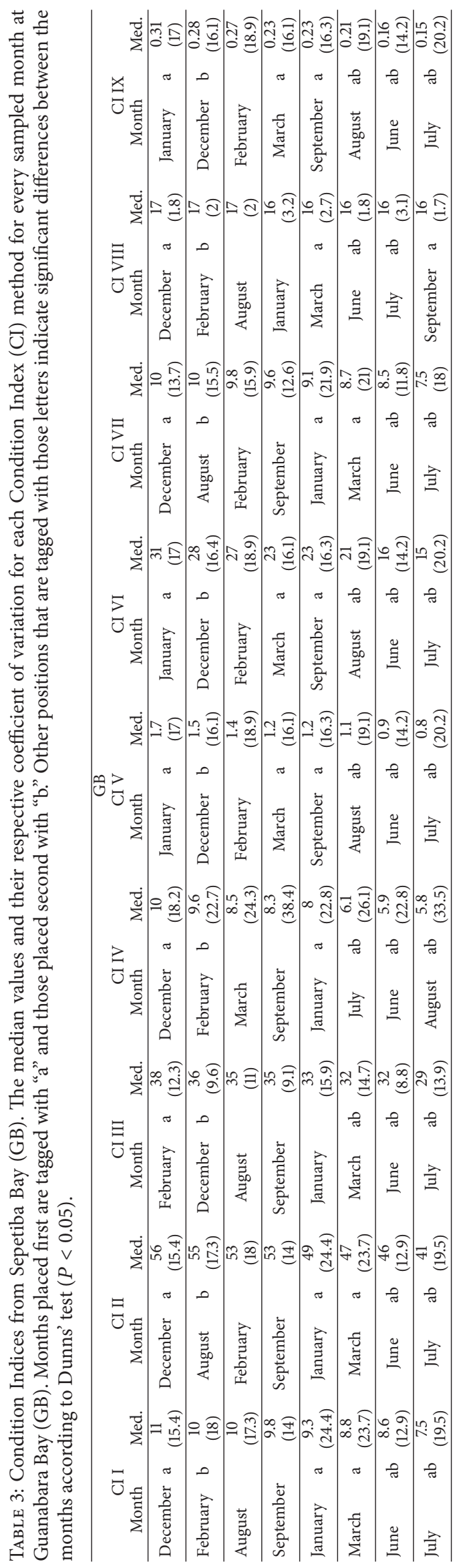


TABle 4: Comparison Condition Indices. Summary of Dunn's test in the comparison between all Condition Indices (CIs) obtained by every method for each sampling site: Sepetiba Bay (SB); Ilha Grande Bay (IGB); and Guanabara Bay (GB). "Yes" and "no" refer to the presence or absence of significant differences, respectively $(P<0.05)$.

\begin{tabular}{lccc}
\hline Method & BS X BIG & BS X BG & BIG X BG \\
\hline CI I & Yes & No & No \\
CI II & Yes & No & No \\
CI III & Yes & No & Yes \\
CI IV & Yes & No & Yes \\
CI V & Yes & Yes & Yes \\
CI VI & Yes & Yes & Yes \\
CI VII & Yes & No & No \\
CI VIII & Yes & No & Yes \\
CI IX & Yes & Yes & Yes \\
\hline
\end{tabular}

almost every sequence. March is the exception at IGB for methods CI I, CI II, and CI III, where this month appears in penultimate position. It is also important to highlight that, in every rank, a significant difference is observed between the first two and the last two ranked months.

When all sampling months from each sampling site are grouped by CI calculation method, a normal distribution is only detected at GB for methods III, IV, VII, and XIII and at IGB only for methods IV and VIII. Therefore, all data was treated as nonparametric.

When we consider the results of all sampling months, the Kruskall-Wallis analysis shows a significant difference between the variances of each bay for all tested methods. Dunn's post hoc test shows that SB has significantly higher CI values when compared to IGB for all nine methods and that GB presents significantly higher CI values in relation to IGB for six methods. When GB and SB are directly compared, only three methods showed significantly higher CIs at $\mathrm{SB}$, and no difference is observed for the other methods (Table 4).

\section{Discussion}

Previous reviews have already stated that the best method for assessing bivalve physiological condition is the net growth efficiency [4]. Such types of CI calculations, classified as "dynamic" methods, are able to detect short term changes due to nutritional status or stress. However, the focus of the present study was to assess the commercial quality of the animals and which "static" methods used in the estimation of CI values should be considered for this purpose [39]. In general, we can consider that, in cases where no significant difference is detected in comparing results derived from a single CI method applied for set data, two situations can be considered: (1) there is really no difference between the animal's health states of the studied sites; (2) the method in question is not able to detect the existing difference because, for example, it generates highly variable data. Performing an overview on results from the CI methods used in the present study, a general agreement between the distinct approaches is reached. The highest CI values are found in the summer months (especially December) and the lowest ones in winter, suggesting a seasonal effect (Tables 1 to 3 ). In spite of that, it is not possible to reach a complete agreement about the differences between the CI values when we compare SB X GB and IGB X GB (Table 4). This is due to the fact that some CI methods show significant differences between the bays, while others do not. Therefore, the authors would suggest an interpretation for the case where a significant difference between two sites is detected by one method but not by the other one. This may be understood as a better resolution power of the CI method that was able to detect the existing differences between the bays. With this in mind, we would suggest methods CI V, VI, and IX to be adopted by subsequent studies, since they showed significant differences between the studied areas while the other methods did not.

Taking a closer look at the equations, it seems that tissue water content does not play an important role in these analyses, since we reached the same conclusions in equations $\mathrm{V}$ ([soft tissue fresh weight $(\mathrm{g})] \times[\text { shell length }(\mathrm{mm})]^{-1} \times$ $100)$ and VI ([soft tissue dry weight $(\mathrm{g})] \times 100 \times[$ shell length $(\mathrm{cm})]^{-1}$ ), suggesting that fisherman could use the CI V.

The requirement of standardizing the water content in bivalves' soft tissue has been suggested by previous studies, since bivalves increase water uptake in poor physiological conditions, such as exposure to a prolonged starvation period [4]. Considering that the studied bays are more likely to be in high eutrophication states, the animals reared in such water bodies would hardly be exposed, for example, to a starvation period as further discussed.

When comparing the mussel CI values obtained at each bay, it is possible to suggest that SB presents a higher potential for mussel farm activity. Two aspects may help better understand the observed result: the land's use of the bays' surroundings and the geographical physiognomy of the bays. SB and GB have limited communication with the open sea and are surrounded by large urban and/or industrial areas. Because of this, the continental contribution of organic matter and nutrients to these two bays by the untreated sewage disposal promotes aquatic system eutrophication (Molisani et al. [41], Borges et al. [42]), which is then reflected in more food availability to the mussels reared at $\mathrm{SB}$ and GB. On the other hand, IGB is freely connected to the Atlantic Ocean [43], reducing the residence time of the organic matter that is introduced from the continent. Moreover, IGB has minor expressive urban and/or industrial activity installed at its drainage basin, resulting in lesser continental organic matter contribution to the water column. Due to this scenario, food availability seems to be a major factor in determining CI variation, rather than ecosystem contamination, as previously reported for native oysters [37], since the contamination ascribed to $\mathrm{SB}$ and GB has apparently a minor effect on CI values. In order to better estimate the mussel yields from each studied bay, it would be interesting to have access to scientific data regarding the growth rate of mussels reared in SB, IGB, and GB, but so far this piece of information is not available. Thus, it is not possible to evaluate if the lower CI values observed in IGB could be overcome by a higher growth rate, resulting in a similar final annual yield in IGB when compared to SB and GB. 
TABLE 5: Condition Indices from different sites around the world. A comparative summary of the CI values (in different units) from different sites around the world obtained with the same methods used in this study. Results of the present study are also presented, showing the range observed over the three study areas. The sites are classified as polluted (Poll.) or unpolluted (Unpoll.) in accordance with the description of their respective papers. Original data from the cited papers that use different units were transformed to the same units used in the present study.

\begin{tabular}{|c|c|c|c|c|c|}
\hline Method & Species & Site & Poll./Unpoll. & Range & Reference \\
\hline \multirow{4}{*}{ CI I } & Mytilus edulis & $\begin{array}{l}\text { Conwy Estuary (North Wales), } \\
\text { UK }\end{array}$ & Unpoll. & $8.51-11.67$ & {$[12]$} \\
\hline & Modiolus barbatus & $\begin{array}{l}\text { Mali Ston Bay (South Adriatic } \\
\text { Sea), Croatia }\end{array}$ & Unpoll. & $9.0-18.5$ & {$[13]$} \\
\hline & Geukensia demissa & Buzzards Bay (Florida), USA & - & $4.0-11.0$ & {$[14]$} \\
\hline & Perna perna & Rio de Janeiro Coast, Brazil & & $7.05-14.6$ & Present study \\
\hline \multirow{4}{*}{ CI II } & M. edulis & $\begin{array}{l}\text { Conwy Estuary (North Wales), } \\
\text { UK }\end{array}$ & Unpoll. & $47.32-58.49$ & {$[12]$} \\
\hline & M. edulis & British Columbia, Canada & Poll./Unpoll. & $82-142$ & {$[15]$} \\
\hline & M. edulis & (North Sea), Germany & Unpoll. & $20.0-135.0$ & {$[16]$} \\
\hline & P. perna & Rio de Janeiro Coast, Brazil & & $38.05-77.45$ & Present study \\
\hline \multirow{4}{*}{ CI III } & $\begin{array}{l}\text { Mytilus } \\
\text { galloprovincialis }\end{array}$ & Nice Bay, France & Poll. & $14.1-29.7$ & {$[17]$} \\
\hline & P. perna & São Paulo Coast, Brazil & - & $17-32$ & {$[18]$} \\
\hline & $\begin{array}{l}\text { M. edulis and } \\
\text { Mytilus trossulus }\end{array}$ & Gaspé Bay (Quebec), Canada & Unpoll. & $44.0-65.0$ & {$[19]$} \\
\hline & P. perna & Rio de Janeiro Coast, Brazil & & $27.5-43.6$ & Present study \\
\hline \multirow{4}{*}{ CI V } & M. edulis & Elliott Bay (West Coast), USA & Poll. & $4.0-8.5$ & {$[10]$} \\
\hline & M. edulis & $\begin{array}{l}\text { Lauritzen Channel (East Coast), } \\
\text { USA }\end{array}$ & Poll. & $8.3-10.3$ & {$[20]$} \\
\hline & M. galloprovincialis & $\begin{array}{l}\text { Limski Kanal (Northern } \\
\text { Adriatic), Croatia }\end{array}$ & Unpoll & $7.6-11.3$ & {$[21]$} \\
\hline & P. perna & Rio de Janeiro Coast, Brazil & & $7.47-20.14$ & Present study \\
\hline \multirow{4}{*}{ CI VI } & M. edulis & San Francisco Bay, USA & Poll. & $3.7-4.6$ & {$[22]$} \\
\hline & M. galloprovincialis & $\begin{array}{l}\text { Alfacs Bay (Mediterranean Sea), } \\
\text { Spain }\end{array}$ & - & $10.4-17.4$ & {$[23]$} \\
\hline & Perna viridis & $\begin{array}{l}\text { Hong Kong (eastern shores), } \\
\text { China }\end{array}$ & Poll. & $4.61-6.55$ & {$[24]$} \\
\hline & P. perna & Rio de Janeiro Coast, Brazil & & $13.8-37.9$ & Present study \\
\hline \multirow{3}{*}{ CI VII } & P. perna & $\begin{array}{l}\text { Guayacán (north coast of Sucre), } \\
\text { Venezuela }\end{array}$ & Unpoll. & $11.64-19.49$ & {$[6]$} \\
\hline & P. perna & $\begin{array}{l}\text { Ensenada de Turpialito, } \\
\text { Venezuela }\end{array}$ & Unpoll. & $12.06-19.1$ & {$[6]$} \\
\hline & P. perna & Rio de Janeiro Coast, Brazil & & $7.08-13.63$ & Present study \\
\hline \multirow{4}{*}{ CI VIII } & Perna canaliculus & Stewart Island, New Zealand & - & $12.2-27.5$ & {$[25]$} \\
\hline & M. galloprovincialis & $\begin{array}{l}\text { Ensenada Pier (Baja California), } \\
\text { México }\end{array}$ & Poll. & $25.5-50.0$ & {$[26]$} \\
\hline & M. edulis & $\begin{array}{l}\text { Loch Etive and Loch Leven, } \\
\text { Scotland }\end{array}$ & Unpoll. & $25.0-55.0$ & {$[27]$} \\
\hline & P. perna & Rio de Janeiro Coast, Brazil & & $15.51-17.2$ & Present study \\
\hline \multirow{4}{*}{ CI IX } & M. edulis & $\begin{array}{l}\text { Coastline of the Inner Danish } \\
\text { Waters, Denmark }\end{array}$ & Poll. & $0.19-1.17$ & {$[28]$} \\
\hline & $\begin{array}{l}\text { M. edulis and } M \text {. } \\
\text { trossulus }\end{array}$ & $\begin{array}{l}\text { Halifax Harbor, Nova Scotia, } \\
\text { Canada }\end{array}$ & Poll. & $0.5-1.3$ & {$[29]$} \\
\hline & M. trossulus & $\begin{array}{l}\text { Gulf of Gdańsk (Southern } \\
\text { Baltic), Poland }\end{array}$ & Poll. & $0.1-0.8$ & {$[30]$} \\
\hline & P. perna & Rio de Janeiro Coast, Brazil & & $0.14-0.59$ & Present study \\
\hline
\end{tabular}


To evaluate the seasonality effect on mussel CI we sampled animals monthly during eight months (summer and winter). Our results show a pronounced seasonality effect on the CI values, where the beginning of summer is shown to be the best season to harvest the reared animals. This data is in agreement with the CI for P. perna from the São Paulo State Coast (southeastern Brazil) that shows higher CIs in October and November and lower CIs in April and May [18]. However, in another study conducted with P. perna at the São Paulo Coast, the authors found no seasonal effect on the growth and yield of seeds [44]. In a previous study conducted with P. perna in southern Brazil, the authors have proposed the end of spring as the best time for harvesting the mussels [45] in accordance with our data that shows December as the month that presents the higher CI (Spring in Brazil ends officially on 20 December). P. perna mussels cultivated in Venezuela showed a tendency to present higher CIs in January, with an expressive increase from December onwards [46], and it has also demonstrated that the CI is not influenced by mussel gender. It has been stated that $P$. perna presents partial spawning and fast recovery during the summer time at subtropical climates, due to the high food availability and relatively low temperature variation [44]. Although we did not determine the gametogenic stage of the animals analyzed in this study, our results are in accordance with this scenario. The seasonality influence on mussel CI values has already been reported for Mytilus galloprovincialis reared in the middle of the Adriatic Sea that suggest the end of autumn and winter as the optimum times for harvesting [47].

Data about tropical environments is still quite scarce, so one should consider climate differences before comparing the results from the present study with reports from other sites around the world. Taking this into account, when compiling the available data in the literature referring to the same CI methods adopted in the present approach, we observed no expressive discrepancies in relation to the observed range of the CI values (Table 5). The consensus between the data available in the literature and the results of the present study suggested that $\mathrm{CI}$ values are less affected by high latitudes of other studied sites (e.g., Coastline of the Inner Danish Waters, Denmark) or by the levels of pollution at the sampling sites (polluted/unpolluted).

\section{Conclusions}

There are many lines of evidence of seasonal variation on CI values, with higher values in the summer. An overview of the results obtained by the nine methods indicates that Sepetiba Bay with midlevels of contamination shows the highest production potential. Considering the sensitivity of the evaluated CI methods, CI V ([soft tissue fresh weight (g)] $\left.\times[\text { shell length }(\mathrm{mm})]^{-1} \times 100\right)$ indicated the best harvest time and the most favorable area to develop mussel farming.

\section{Conflict of Interests}

The authors declare that there is no conflict of interests regarding the publication of this paper.

\section{Acknowledgments}

The authors are pleased to thank the local shell fisherman from Guanabara Bay, Mr. Glauco, for providing all the logistic support in the fieldwork. They also thank Castelo Branco University for the collaboration of its experimental mussel farm at Sepetiba Bay. The Instituto de Ecodesenvolvimento da Baía de Ilha Grande (POMAR Project) made the sampling feasible at Ilha Grande Bay, so the authors are deeply grateful to all collaborations in this work. This study was funded by CAPES/PROBRAL (270/07) and CNPq/MAPA/SDA (577906/2008-9).

\section{References}

[1] FAO, World aquaculture production of fish, crustaceans, molluscs, etc., by principal species in 2009, 2010, (ftp://ftp.fao.org/fi/stat/summary/a-6.pdf).

[2] E. Orban, G. Di Lena, T. Nevigato, I. Casini, A. Marzetti, and R. Caproni, "Seasonal changes in meat content, condition index and chemical composition of mussels (Mytilus galloprovincialis) cultured in two different Italian sites," Food Chemistry, vol. 77, no. 1, pp. 57-65, 2002.

[3] G. Sasikumar and P. K. Krishnakumar, "Aquaculture planning for suspended bivalve farming systems: the integration of physiological response of green mussel with environmental variability in site selection," Ecological Indicators, vol. 11, no. 2, pp. 734-740, 2011.

[4] A. Lucas and P. G. Beninger, "The use of physiological condition indices in marine bivalve aquaculture," Aquaculture, vol. 44, no. 3, pp. 187-200, 1985.

[5] M. Bressan and M. G. Marin, "Seasonal variations in biochemical composition and condition index of cultured mussels (Mytilus galloprovincialis Lmk) in the Lagoon of Venice (North Adriatic)," Aquaculture, vol. 48, no. 1, pp. 13-21, 1985.

[6] M. Narváez, L. Freites, M. Guevara et al., "Food availability and reproduction affects lipid and fatty acid composition of the brown mussel, Perna perna, raised in suspension culture," Comparative Biochemistry and Physiology -B Biochemistry and Molecular Biology, vol. 149, no. 2, pp. 293-302, 2008.

[7] A. Vélez and C. E. Epifanio, "Effects of temperature and ration on gametogenesis and growth in the tropical mussel Perna perna (L.)," Aquaculture, vol. 22, pp. 21-26, 1981.

[8] D. M. Pampanin, E. Volpato, I. Marangon, and C. Nasci, "Physiological measurements from native and transplanted mussel (Mytilus galloprovincialis) in the canals of Venice. Survival in air and condition index," Comparative Biochemistry and Physiology-A Molecular and Integrative Physiology, vol. 140, no. 1, pp. 41-52, 2005.

[9] N. Carro, I. García, M. Ignacio, and A. Mouteira, "Spatial and temporal trends of PCBs (polychlorinated biphenyls) in mussel from Galician coast (1998-2008)," Environment International, vol. 36, no. 8, pp. 873-879, 2010.

[10] A. N. Kagley, R. G. Snider, P. K. Krishnakumar, and E. Casillas, "Assessment of seasonal variability of cytochemical responses to contaminant exposure in the blue mussel Mytilus edulis (complex)," Archives of Environmental Contamination and Toxicology, vol. 44, no. 1, pp. 43-52, 2003.

[11] F. C. Fernandes, R. C. C. L. de Souza, A. O. R. Junqueira et al., "Distribuição Mundial e o Impacto de sua Introdução no 
Brasil," in O Mexilhão Perna perna Biol. Ecol. e Apl., C. ResgallaJunior, L. I. Weber, and M. B. da Conceição, Eds., pp. 25-29, Interciência, Rio de Janeiro, Brazil, 1st edition, 2008.

[12] J. Davenport and X. Chen, "A comparison of methods for the assessment of condition in the mussel (Mytilus edulis L.)," Journal of Molluscan Studies, vol. 53, no. 3, pp. 293-297, 1987.

[13] I. Mladineo, M. Peharda, S. Orhanović, J. Bolotin, M. PavelaVrančić, and B. Treursić, "The reproductive cycle, condition index and biochemical composition of the horse-bearded mussel Modiolus barbatus," Helgoland Marine Research, vol. 61, no. 3, pp. 183-192, 2007.

[14] J. B. Culbertson, I. Valiela, Y. S. Olsen, and C. M. Reddy, "Effect of field exposure to 38-year-old residual petroleum hydrocarbons on growth, condition index, and filtration rate of the ribbed mussel, Geukensia demissa," Environmental Pollution, vol. 154, no. 2, pp. 312-319, 2008.

[15] J. A. Grout and C. D. Levings, "Effects of acid mine drainage from an abandoned copper mine, Britannia Mines, Howe Sound, British Columbia, Canada, on transplanted blue mussels (Mytilus edulis)," Marine Environmental Research, vol. 51, no. 3, pp. 265-288, 2001.

[16] M. Brenner, S. Ramdohr, S. Effkemann, and M. Stede, "Key parameters for the consumption suitability of offshore cultivated blue mussels (Mytilus edulis L.) in the German Bight," European Food Research and Technology, vol. 230, no. 2, pp. 255267, 2009.

[17] M. Roméo, P. Hoarau, G. Garello, M. Gnassia-Barelli, and J. P. Girard, "Mussel transplantation and biomarkers as useful tools for assessing water quality in the NW Mediterranean," Environmental Pollution, vol. 122, no. 3, pp. 369-378, 2003.

[18] M. B. Henriques, H. L. de Almeida Marques, W. Barrella, and O. Martins Pereira, "Estimativa do Tempo de Recuperação de um Banco Natural do Mexilhão Perna perna (Linnaeus, 1758) na Baía de Santos, Estado de São Paulo," HOLOS Envronment, vol. 1, pp. 85-100, 2001.

[19] S. Cartier, J. Pellerin, M. Fournier, E. Tamigneaux, L. Girault, and N. Lemaire, "Use of an index based on the blue mussel (Mytilus edulis and Mytilus trossulus) digestive gland weight to assess the nutritional quality of mussel farm sites," Aquaculture, vol. 241, no. 1-4, pp. 633-654, 2004.

[20] J. E. Tomaszewski, P. B. McLeod, and R. G. Luthy, "Measuring and modeling reduction of DDT availability to the water column and mussels following activated carbon amendment of contaminated sediment," Water Research, vol. 42, no. 16, pp. 4348-4356, 2008.

[21] B. Hamer, Z. Jaksic, D. Pavicic-Hamer et al., "Effect of hypoosmotic stress by low salinity acclimation of Mediterranean mussels Mytilus galloprovincialis on biological parameters used for pollution assessment," Aquatic Toxicology, vol. 89, no. 3, pp. 137-151, 2008.

[22] M. Martin, G. Ichikawa, J. Goetzl, M. de los Reyes, and M. D. Stephenson, "Relationships between physiological stress and trace toxic substances in the bay mussel, Mytilus edulis, from San Francisco bay, California," Marine Environmental Research, vol. 11, no. 2, pp. 91-110, 1984.

[23] E. Galimany, M. Ramón, and I. Ibarrola, "Feeding behavior of the mussel Mytilus galloprovincialis (L.) in a Mediterranean estuary: a field study," Aquaculture, vol. 314, pp. 236-243, 2011.

[24] J. K. H. Fang, R. S. S. Wu, G. J. Zheng, P. K. Lam, and P. K. Shin, "Induction, adaptation and recovery of lysosomal integrity in green-lipped mussel Perna viridis," Marine Pollution Bulletin, vol. 57, no. 6-12, pp. 467-472, 2008.
[25] A. G. Taylor and C. Savage, "Fatty acid composition of New Zealand green-lipped mussels, Perna canaliculus: implications for harvesting for n-3 extracts," Aquaculture, vol. 261, no. 1, pp. 430-439, 2006.

[26] J. Cáceres-Martínez, R. Vásquez-Yeomans, and R. Sluys, “The turbellarian Urastoma cyprinae from edible mussels Mytilus galloprovincialis and Mytilus californianus in Baja California, NW México," Journal of Invertebrate Pathology, vol. 72, no. 3, pp. 214-219, 1998.

[27] I. Okumus and H. P. Stirling, "Seasonal variations in the meat weight, condition index and biochemical composition of mussels (Mytilus edulis L.) in suspended culture in two Scottish sea lochs," Aquaculture, vol. 159, no. 3-4, pp. 249-261, 1998.

[28] K. Granby and N. H. Spliid, "Hydrocarbons and organochlorines in common mussels from the kattegat and the belts and their relation to condition indices," Marine Pollution Bulletin, vol. 30, no. 1, pp. 74-82, 1995.

[29] J. Hellou, P. Yeats, S. Steller, and F. Gagné, "Chemical contaminants and biological indicators of mussel health during gametogenesis," Environmental Toxicology and Chemistry, vol. 22, no. 9, pp. 2080-2087, 2003.

[30] K. Pierścieniak and J. Grzymała, "Differences in reproduction and condition of Macoma balthica and Mytilus trossulus in the Gulf of Gdańsk (Southern Baltic Sea) under anthropogenic influences," Oceanological and Hydrobiological Studies, vol. 39, no. 4, pp. 17-32, 2010.

[31] G. Perin, R. Fabris, S. Manente, A. R. Wagener, C. Hamacher, and S. Scotto, "A five-year study on the heavy-metal pollution of Guanabara Bay sediments (Rio de Janeiro, Brazil) and evaluation of the metal bioavailability by means of geochemical speciation," Water Research, vol. 31, no. 12, pp. 3017-3028, 1997.

[32] B. Kjerfve, C. H. A. Ribeiro, G. T. M. Dias, A. M. Filippo, and V. D. S. Quaresma, "Oceanographic characteristics of an impacted coastal bay: Baía de Guanabara, Rio de Janeiro, Brazil," Continental Shelf Research, vol. 17, no. 13, pp. 1609-1643, 1997.

[33] H. Lage and S. Jablonski, "Mussel Perna perna extraction and commercialization in Guanabara Bay, Brazil," Atlântica, vol. 30, pp. 161-169, 2008.

[34] J. Japenga, W. J. Wagenaar, W. Salomons, L. D. Lacerda, S. R. Patchineelam, and C. M. Leitao Filho, "Organic micropollutants in the Rio de Janeiro coastal region, Brazil," Science of the Total Environment, vol. 75, no. 2-3, pp. 249-259, 1988.

[35] N. V. Freret-Meurer, J. V. Andreata, B. C. Meurer et al., "Spatial distribution of metals in sediments of the Ribeira Bay, Angra dos Reis, Rio de Janeiro, Brazil," Marine Pollution Bulletin, vol. 60, no. 4, pp. 627-629, 2010.

[36] H. L. A. Marques, "Aspectos relativos a produção," in Criação Comer. Mexlhões, H. L. A. Marques, Ed., pp. 77-81, Nobel, São Paulo, Brazil, 1998.

[37] M. F. Rebelo, M. C. Amaral, and W. C. Pfeiffer, "Oyster condition index in Crassostrea rhizophorae (Guilding, 1828) from a heavy-metal polluted coastal lagoon," Brazilian Journal of Biology, vol. 65, no. 2, pp. 345-351, 2005.

[38] R. W. Hickman and J. Illingworth, "Condition cycle of the green-lipped mussel Perna canaliculus in New Zealand," Marine Biology, vol. 60, no. 1, pp. 27-38, 1980.

[39] J. S. Rainer and R. Mann, "A comparison of methods for calculating condition index in eastern oysters, Crassostrea virginica, (Gmelin, 1791)," Journal of Shellfish Research, vol. 11, pp. 55-58, 1992. 
[40] V. K. Mubiana, K. Vercauteren, and R. Blust, "The influence of body size, condition index and tidal exposure on the variability in metal bioaccumulation in Mytilus edulis," Environmental Pollution, vol. 144, no. 1, pp. 272-279, 2006.

[41] M. M. Molisani, R. V. Marins, W. Machado, H. H. M. Paraquetti, E. D. Bidone, and L. D. Lacerda, "Environmental changes in Sepetiba Bay, SE Brazil," Regional Environmental Change, vol. 4, no. 1, pp. 17-27, 2004.

[42] A. C. Borges, C. J. Sanders, H. L. R. Santos, D. R. Araripe, W. Machado, and S. R. Patchineelam, "Eutrophication history of Guanabara Bay (SE Brazil) recorded by phosphorus flux to sediments from a degraded mangrove area," Marine Pollution Bulletin, vol. 58, no. 11, pp. 1750-1754, 2009.

[43] J. V. Guerra and F. L. M. Soares, "Circulation and flux of suspended particulate matter in Ilha Grande Bay, SE Brazil," Journal of Coastal Research, vol. 56, pp. 1350-1354, 2009.

[44] H. L. D. A. Marques, R. T. L. Pereira, and B. C. Correa, "Seasonal variation in growth and yield of the brown mussel Perna perna (L.) cultured in Ubatuba, Brazil," Aquaculture, vol. 169, no. 3-4, pp. 263-273, 1998.

[45] A. W. C. Marenzi and J. O. Branco, Omexilhão Perna perna (Linnaeus) (Bivalvia, Mytilidae) emcultivo cultivona Armação do Itapocoroy, vol. 22, Brasil Armação Itapocor pocoro, Santa Catarina, Brasil, 2005.

[46] D. Arrieche, B. Licet, N. García, C. Lodeiros, and A. Prieto, "Índice de condición, gonádico y de rendimiento del mejillón marrón Perna perna (Bivalvia: Mytilidae), del morro de guarapo, Venezuela," Interciencia, vol. 29, pp. 613-619, 2002.

[47] M. Peharda, I. Župan, L. Bavčević, A. Frankić, and T. Klanjšček, "Growth and condition index of mussel Mytilus galloprovincialis in experimental integrated aquaculture," Aquaculture Research, vol. 38, no. 16, pp. 1714-1720, 2007. 

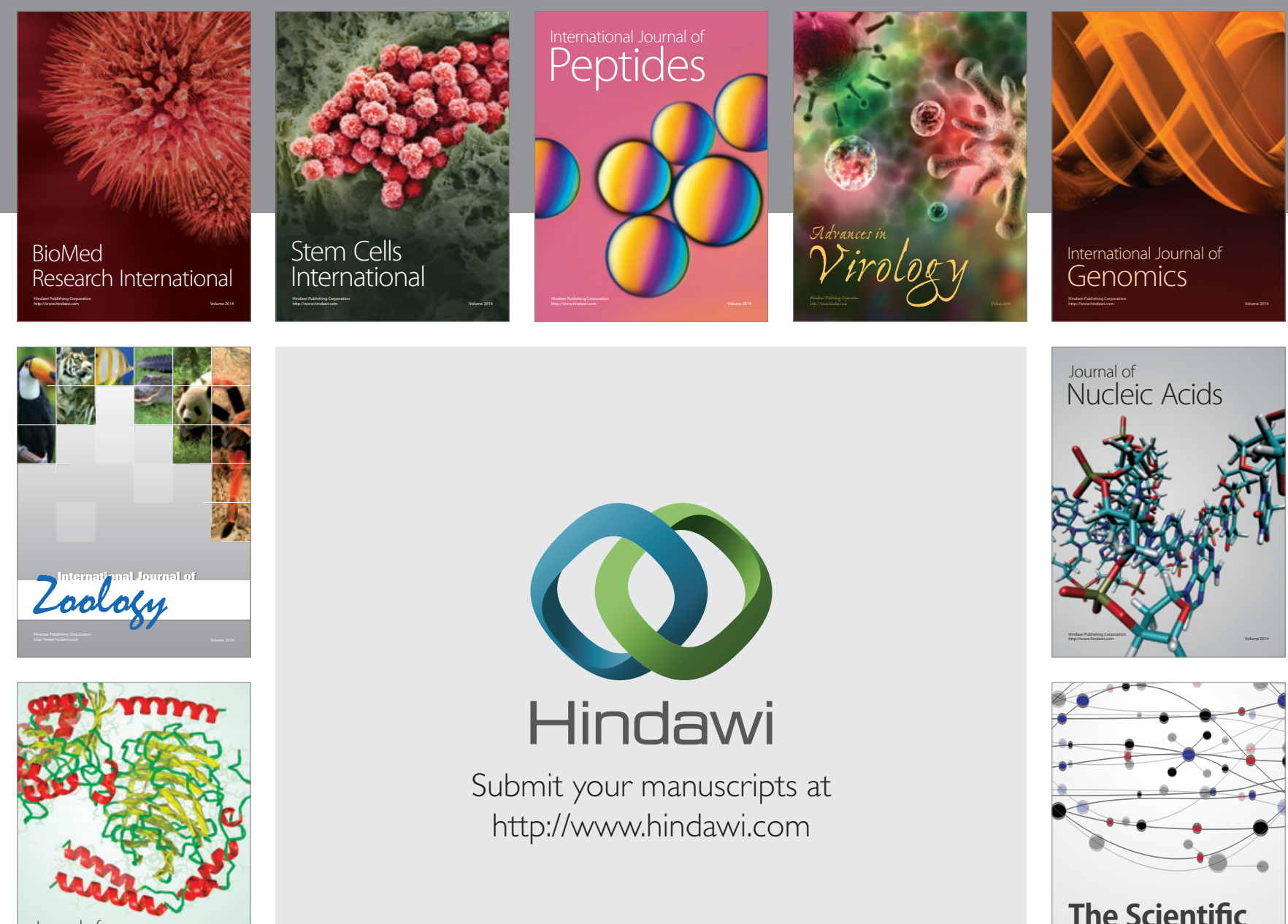

Submit your manuscripts at

http://www.hindawi.com

Journal of
Signal Transduction
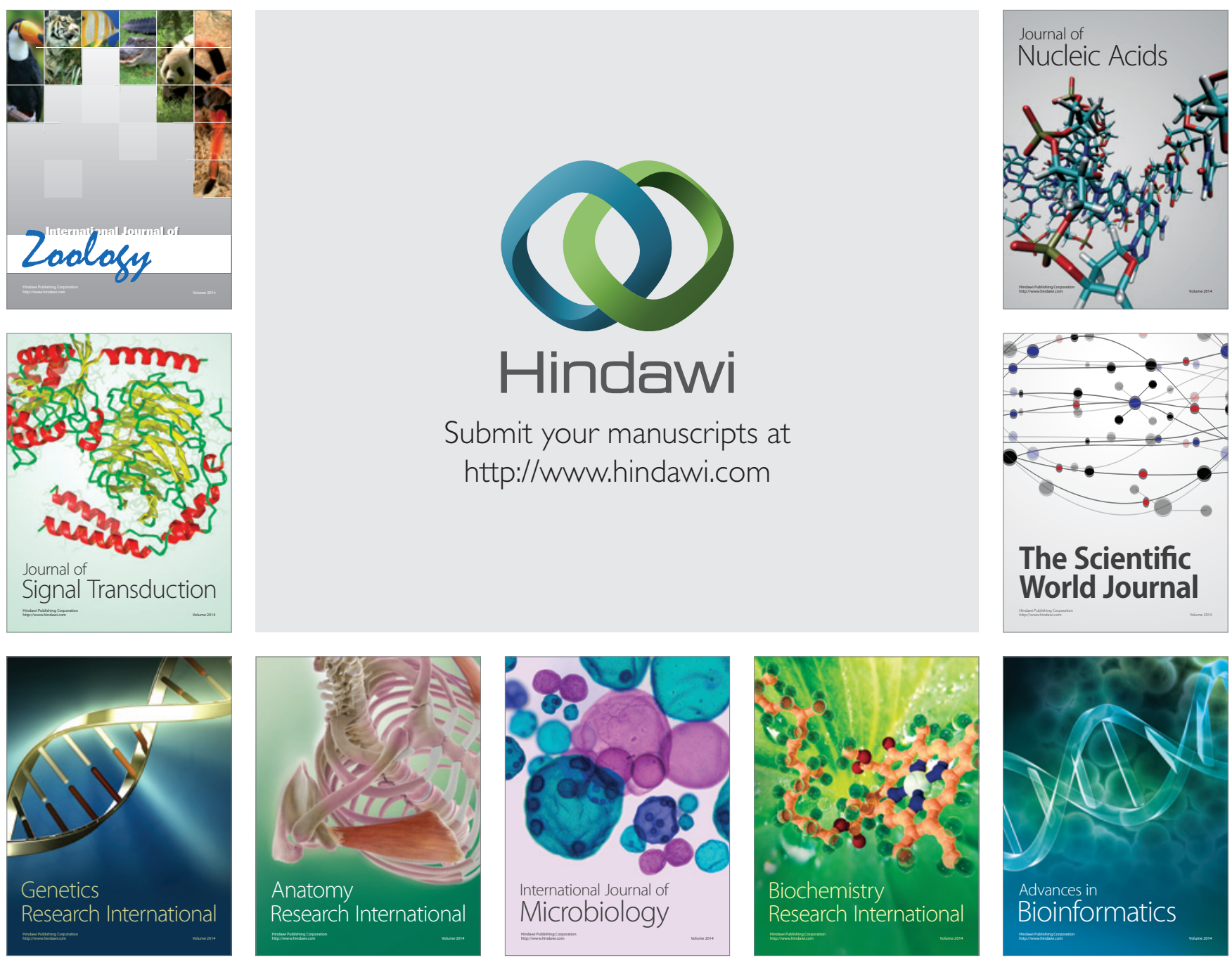

The Scientific World Journal
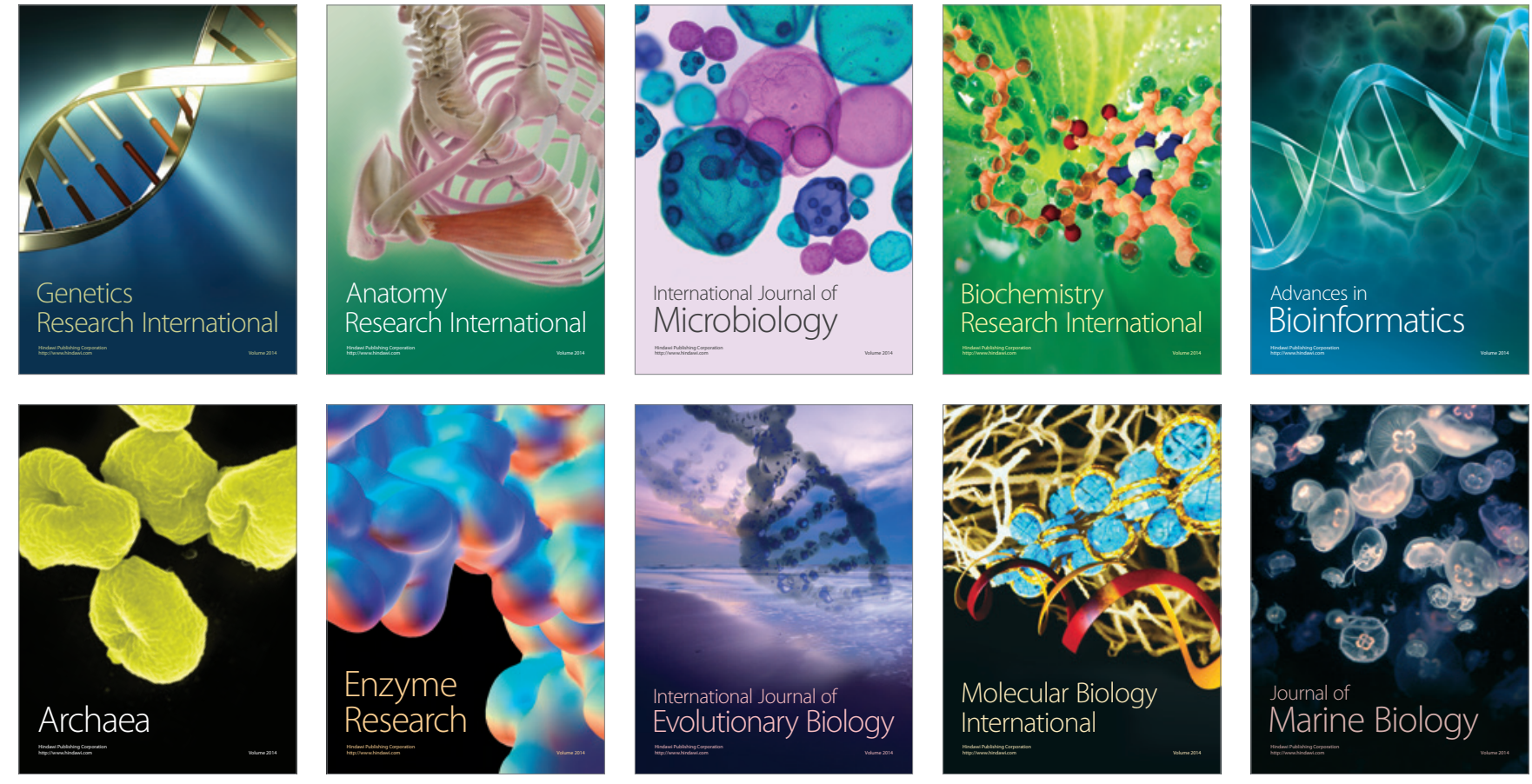